\title{
Evaluation of Mango (Mangifera indica L.) Rootstocks under Induced Moisture Stress Condition for Various Morpho-Physiological Traits
}

\author{
L. Shanthala*, R. K. Ramachandra, S. Mohan Kumar, G. S. K. Swamy, \\ M. K. Honnabyraiah and H. M. Pallavi
}

Department of Fruit Science, College of Horticulture, UHS Campus, Vignana Kendra, Bengaluru-560065, Karnataka, India

*Corresponding author

\section{Keywords}

Moisture stress, rootstocks, field capacity, stress tolerance

\section{Article Info}

Accepted:

12 April 2021

Available Online: 10 May 2021
The present study was conducted to evaluate mango (Mangifera indica L.) rootstocks under induced moisture stress condition for various morpho-physiological traits. The result revealed that the rootstock Totapuri recorded minimum plant height $(23.55 \mathrm{~cm})$, stem diameter $(1.16 \mathrm{~cm})$, leaf area $\left(380.30 \mathrm{~cm}^{2}\right)$, stomatal density $\left(78.36 \mathrm{No} . / \mathrm{mm}^{2}\right)$, plant biomass $(98.00 \mathrm{~g})$ and maximum relative water content $(90.26 \%)$. Among the different stress level, lower plant height $(23.93 \mathrm{~cm})$, stem diameter $(1.27 \mathrm{~cm})$, relative water content $(77.49 \%)$, leaf area $\left(463.59 \mathrm{~cm}^{2}\right)$, stomatal density $\left(80.97 \mathrm{No} / \mathrm{mm}^{2}\right)$ and plant biomass (97.66 g) was found in severely stressed treatment. However interaction effect showed that Totapuri rootstocks under severe stressed condition recorded minimum plant height $(22.65 \mathrm{~cm})$, stem diameter $(1.04 \mathrm{~cm})$, leaf area $\left(352.32 \mathrm{~cm}^{2}\right)$, stomatal density $\left(70.51 \mathrm{No} . / \mathrm{mm}^{2}\right)$, plant biomass $(96.31 \mathrm{~g})$ and maximum relative water content $(94.25 \%)$. The rootstock Totapuri clearly shows the survivable strategies under severe stressed period by reducing its plant height, stem diameter, leaf area. As by reducing crop canopy there will be reduced water loss through transpiration and evaporation rate. More rapid reduction in stomatal density and ability to maintain higher relative water content under stressed period were the chief physiological adaptations characterized by rootstock Totapuri and Alphonso to tolerate stress condition.

\section{Introduction}

Mango (Mangifera indica L.) is an economically important fruit crop of India, belongs to the family Anacardiaceae. There are more than one thousand varieties and the crop was cultivated in Indian sub-continent since 4000 years. It is the national fruit of
India and acknowledged as "King of Fruits". The mango fruit is an excellent source of vitamin $\mathrm{A}$ and potassium. $100 \mathrm{~g}$ fruit is said to provide $4800 \mathrm{IU}$ of vitamin A, $156 \mathrm{mg}$ of potassium with just $2 \mathrm{mg}$ of sodium. The mango is very nutritious having greater health benefits both, when eaten raw and as a ripened. The fruit (ripe and unripe), seed, 
bark, leaves, root and even the smoke of burning leaves have healing properties. It is known to be a very good source of vitamins such as, vitamin-C, riboflavin, thiamine, niacin and $B$-carotene. Apart from the use of ripe mango, young and unripe fruits are utilized for culinary purposes as well as for preparing pickles, chutneys and amchur.

Moisture stress is one of the most significant abiotic stress factor limiting global production. Plants exhibit number of physiological and biochemical responses at cellular and whole organism level on account of water stress environment. Moisture stress is characterized by decrease in water content, diminished leaf water potential and turgor loss, closure of stomata and reduced cell enlargement and growth. This situation may result in the arrest of photosynthesis, interruption of metabolism and finally the death of plant (Jaleel et al., 2008). Reducing canopy leaf area, stomatal conductance, deeper penetration of roots, higher relative water content and enhanced osmotic adjustment are some the mechanism that plant employ to overcome plant stress.

\section{Materials and Methods}

An experiment was conducted at University of Horticultural Sciences, Bagalkot, Horticulture research and extension centre (HREC), Hogalagere, Kolar, Karnataka (India) during the year 2019-2020 in a Factorial Completely Randomized Block Design (FCRD).There were 16 treatments with five replications and 10 plants in each replication. Six month old rootstocks of Alphonso, Dashehari, Neelum and Totapuri were treated with four different stress levels (100\% of FC- Control; $80 \%$ of FC- moderate stress; $60 \%$ of FC- mild stress and $40 \%$ of FC- severe stress). Stress was imposed by withholding watering for 15 days and on $16^{\text {th }}$ day plants were irrigated up to 100 per cent of FC and again stress was created for another 15 days. Six such serial stress cycles were given to study the variations among the rootstocks under the stress period ( $1^{\text {st }}$ January to April $4^{\text {th }}$ ). Later on seedlings were allowed to recover by irrigating daily (100\% of FC) in the month of April (recovery period). Observations were recorded at monthly interval and pooled data were subjected to statistical analysis as per the procedure outlined by Panse and Sukhatme (1985) and the treatment means were compared by critical difference values computed at 5\% level of significance. Leaf area was measured by leaf area meter, Relative water content was measured as per the procedure of Barrs and Weatherlay's (1962), Stomatal density was measured by thermocol- xylene impression method (Wolf et al., 1979).

\section{Results and Discussion}

\section{Plant height}

During stress induction period and at recovery period, Totapuri under severe stress treatment recorded minimum plant height $(22.65 \mathrm{~cm}$ and $23.40 \mathrm{~cm}$ respectively).Similarly, in case of Kent mango, reduced irrigation treatments significantly reduce the vegetative growth in comparison to the control (Pavel Devilliers, 2004).The reduced plant height is usually associated with a decline in the cell enlargement under water deficit which is greatly hampered because of low moisture content (Bhatt and Srinivasa Rao, 2005).

\section{Stem diameter}

Minimum stem diameter was observed in Dashehari under moderate stress treatment during stress period $(1.04 \mathrm{~cm})$ and at recovery period $(1.21 \mathrm{~cm})$. As there was increase in the water stress the diameter of stem was decreased to reduce the water loss from the plant. Under water stress, declination in stem diameter was due to the loss of cell turgor which suppresses cell expansion and 
enlargement there by, inhibiting the growth of shoot (Bhatt and Srinivasa Rao, 2005). A steady increase in stem diameter was observed in control and mild stress treatment, whereas there was no increase in stem diameter in case of water stress condition (Luvaha et al., 2011).

\section{Plant biomass}

The rootstock Totapuri under mild stressed condition recorded minimum plant biomass during stress period $(96.31 \mathrm{~g})$ and at recovery period $(96.91 \mathrm{~g})$.

Under water stress condition, there is a trend of decrease in plant vegetative growth, number of leaves and plant biomass. These findings are in conformity with Sakalauskaite et al., (2006). They reported that 50 per cent decrease in fresh and dry weights following five weeks of drought treatments in apple rootstocks.

\section{Relative water content (RWC) (\%)}

In control Totapuri rootstock recorded maximum RWC $(94.25 \%$ and $95.41 \%$ respectively) whereas, minimum RWC was recorded in Neelum rootstock under severe stressed condition during stress period (70.91 $\%$ )and Dashehari rootstock under severe stressed in case of recovery period (77.25 $\%)$.RWC was observed to decline in all the rootstocks with increase in water stress level.

The decline in RWC was less in rootstock Totapuri as compared to others. This showed that even under severe stress condition Totapuri rootstock had able to maintain more RWC which is the characteristic of water stress tolerance. All the rootstocks showed a recovery to some extent in all the levels of stress (mild stress, moderate stress and severe stress) and highest recovery was found in
Totapuri under severe stress condition from 46.741 per cent RWC to 50.323 per cent.

\section{Leaf area}

Minimum leaf area was recorded in rootstock Totapuri under severe stressed condition during stress period and at recovery period (352.32 $\mathrm{cm}^{2}$ and $371.73 \mathrm{~cm}^{2}$ respectively). Highest per cent reduction in LA was found in Totapuri $(8.48 \%$ in moderate stress level and $12.61 \%$ in severe stress level period) and least per cent reduction was found in Dashehari under moderate stress level (1.08\%) and Neelum under severe stress level period $(1.049 \%)$.Reduced leaf area growth may be a survival mechanism for the plants to maintain tissue hydration by reducing the rate of transpiration.

These results are in confirmity with those reported by Kadam et al., (2001) in grape rootstocks. According to them, maximum leaf area was observed in variety Salt Creek $\left(101.63 \mathrm{~cm}^{2}\right)$ at 0.3 bar irrigation level and lowest was recorded in $1103-\mathrm{P}\left(32.25 \mathrm{~cm}^{2}\right)$ at 0.7 bar irrigation level. Maximum per cent reduction in leaf area was observed in 1103-P (29.18\% and $54.77 \%$ at 0.5 bar and 0.7 bar respectively) found to be more tolerant rootstocks compared to Dogridge and Salt Creek.

\section{Stomatal density}

The rootstock Totapuri with severe stressed treatment recorded minimum stomatal density (70.51 and 78.71 respectively). This was supported by Zaharaand Razi, 2009.

They showed that the faster rate of reduction in stomatal conductance might be attributed to the tendency of plants to control water loss through transpiration. 
Table.1a Effect of induced moisture stress on morpho-physiological parameters

\begin{tabular}{|c|c|c|c|c|c|c|}
\hline \multirow[t]{2}{*}{ Treatments } & \multicolumn{2}{|c|}{ Plant height $(\mathrm{cm})$} & \multicolumn{2}{|c|}{ Stem diameter $(\mathrm{cm})$} & \multicolumn{2}{|c|}{ Leaf area $\left(\mathrm{cm}^{2}\right)$} \\
\hline & During stress & Recovery & During stress & Recovery & $\begin{array}{c}\text { During } \\
\text { stress }\end{array}$ & Recovery \\
\hline \multicolumn{7}{|c|}{ Factor 1 (Water stress levels) } \\
\hline $\mathbf{I}_{1}$ & 25.60 & 26.86 & 1.33 & 1.42 & 496.55 & 499.45 \\
\hline $\mathbf{I}_{2}$ & 25.14 & 26.30 & 1.36 & 1.41 & 485.93 & 489.05 \\
\hline $\mathbf{I}_{3}$ & 24.10 & 24.55 & 1.35 & 1.38 & 474.10 & 480.31 \\
\hline $\mathbf{I}_{4}$ & 23.93 & 24.10 & 1.27 & 1.37 & 463.59 & 470.87 \\
\hline S.Em \pm & 0.095 & 0.080 & 0.01 & 0.02 & 0.034 & 0.018 \\
\hline CD at $5 \%$ & 0.275 & 0.230 & 0.02 & 0.04 & 0.100 & 0.054 \\
\hline \multicolumn{7}{|c|}{ Factor 2 (Rootstocks) } \\
\hline $\mathbf{V}_{1}$ & 25.75 & 26.66 & 1.43 & 1.48 & 560.01 & 561.38 \\
\hline$V_{2}$ & 24.38 & 25.45 & 1.38 & 1.44 & 520.56 & 523.52 \\
\hline $\mathbf{V}_{3}$ & 25.11 & 24.69 & 1.35 & 1.41 & 459.30 & 461.58 \\
\hline $\mathbf{V}_{4}$ & 23.55 & 26.17 & 1.16 & 1.23 & 380.30 & 393.20 \\
\hline S.Em \pm & 0.09 & 0.080 & 0.01 & 0.02 & 0.034 & 0.018 \\
\hline CD at $5 \%$ & 0.275 & 0.230 & 0.02 & 0.04 & 0.100 & 0.054 \\
\hline \multicolumn{7}{|c|}{ Interaction effects } \\
\hline $\mathbf{I}_{1} \mathbf{V}_{1}$ & 27.39 & 28.27 & 1.47 & 1.54 & 583.44 & 584.12 \\
\hline $\mathbf{I}_{1} \mathbf{V}_{2}$ & 25.10 & 26.37 & 1.17 & 1.22 & 545.83 & 548.33 \\
\hline $\mathbf{I}_{1} \mathbf{V}_{3}$ & 24.02 & 25.43 & 1.39 & 1.39 & 464.82 & 469.82 \\
\hline $\mathbf{I}_{1} \mathbf{V}_{4}$ & 25.90 & 27.37 & 1.36 & 1.40 & 392.11 & 395.53 \\
\hline $\mathbf{I}_{2} \mathbf{V}_{1}$ & 26.26 & 27.69 & 1.46 & 1.50 & 566.14 & 568.42 \\
\hline $\mathbf{I}_{2} \mathbf{V}_{2}$ & 24.80 & 25.61 & 1.27 & 1.31 & 516.24 & 520.52 \\
\hline $\mathbf{I}_{2} \mathbf{V}_{3}$ & 24.10 & 25.39 & 1.30 & 1.34 & 453.61 & 454.16 \\
\hline $\mathbf{I}_{2} \mathbf{V}_{4}$ & 25.39 & 26.51 & 1.42 & 1.47 & 407.74 & 413.11 \\
\hline $\mathbf{I}_{3} \mathbf{V}_{1}$ & 24.80 & 25.17 & 1.37 & 1.42 & 541.81 & 541.26 \\
\hline $\mathbf{I}_{3} \mathbf{V}_{2}$ & 24.43 & 25.46 & 1.11 & 1.44 & 519.71 & 521.13 \\
\hline $\mathbf{I}_{3} \mathbf{V}_{3}$ & 24.52 & 25.51 & 1.33 & 1.41 & 465.84 & 466.43 \\
\hline $\mathbf{I}_{3} \mathbf{V}_{4}$ & 23.85 & 24.18 & 1.35 & 1.44 & 369.04 & 392.41 \\
\hline $\mathbf{I}_{4} \mathbf{V}_{1}$ & 25.30 & 25.63 & 1.41 & 1.46 & 548.64 & 551.71 \\
\hline $\mathbf{I}_{4} \mathbf{V}_{2}$ & 23.18 & 24.34 & 1.14 & 1.19 & 500.46 & 504.10 \\
\hline $\mathbf{I}_{4} \mathbf{V}_{3}$ & 23.42 & 24.55 & 1.40 & 1.48 & 452.94 & 455.92 \\
\hline $\mathbf{I}_{4} \mathbf{V}_{4}$ & 22.65 & 23.40 & 1.04 & 1.21 & 352.32 & 371.73 \\
\hline S.Em \pm & 0.190 & 0.159 & 0.01 & 0.03 & 0.069 & 0.037 \\
\hline CD at $5 \%$ & 0.055 & 0.461 & 0.04 & 0.09 & 0.199 & 0.107 \\
\hline
\end{tabular}

$\mathrm{I}_{1}\left(100 \%\right.$ of FC); $\mathrm{I}_{2}$ (80\% of FC); $\mathrm{I}_{3}\left(60 \%\right.$ of FC); $\mathrm{I}_{4}(40 \%$ of FC)

$\mathrm{V}_{1}$ (Alphonso); $\mathrm{V}_{2}$ (Dashehari); $\mathrm{V}_{3}\left(\right.$ Neelum); $\mathrm{V}_{1}$ (Totapuri) 
Table.1b Effect of induced moisture stress on morpho-physiological parameters

\begin{tabular}{|c|c|c|c|c|c|c|}
\hline \multirow[t]{2}{*}{ Treatments } & \multicolumn{2}{|c|}{$\begin{array}{c}\text { Relative water content } \\
(\%)\end{array}$} & \multicolumn{2}{|c|}{$\begin{array}{c}\text { Stomatal density } \\
\left(\text { No. } / \mathrm{mm}^{2}\right)\end{array}$} & \multicolumn{2}{|c|}{ Plant biomass (g) } \\
\hline & During stress & Recovery & During stress & Recovery & $\begin{array}{l}\text { During } \\
\text { stress }\end{array}$ & Recovery \\
\hline \multicolumn{7}{|c|}{ Factor 1 (Water stress levels) } \\
\hline $\mathbf{I}_{1}$ & 90.68 & 90.98 & 91.49 & 91.81 & 104.93 & 106.17 \\
\hline $\mathbf{I}_{2}$ & 86.40 & 89.02 & 87.64 & 90.28 & 102.28 & 102.92 \\
\hline $\mathbf{I}_{3}$ & 82.42 & 86.39 & 84.6 & 89.22 & 99.22 & 100.50 \\
\hline $\mathbf{I}_{4}$ & 77.49 & 83.49 & 80.97 & 88.39 & 97.66 & 100.10 \\
\hline S.Em \pm & 0.011 & 0.007 & 0.007 & 0.015 & 0.02 & 0.11 \\
\hline CD at $5 \%$ & 0.031 & 0.021 & 0.019 & 0.043 & 0.044 & 0.32 \\
\hline \multicolumn{7}{|c|}{ Factor 2 (Rootstocks) } \\
\hline $\mathbf{V}_{1}$ & 85.62 & 88.04 & 78.57 & 82.26 & 104.94 & 106.40 \\
\hline$V_{2}$ & 79.81 & 83.02 & 84.12 & 87.99 & 101.83 & 102.85 \\
\hline $\mathbf{V}_{3}$ & 81.31 & 85.15 & 103.67 & 107.28 & 99.31 & 101.19 \\
\hline $\mathbf{V}_{4}$ & 90.26 & 93.69 & 78.36 & 82.16 & 98.02 & 99.26 \\
\hline S.Em \pm & 0.011 & 0.007 & 0.007 & 0.015 & 0.02 & 0.11 \\
\hline CD at $5 \%$ & 0.031 & 0.021 & 0.019 & 0.043 & 0.04 & 0.32 \\
\hline \multicolumn{7}{|c|}{ Interaction effects } \\
\hline $\mathbf{I}_{1} \mathbf{V}_{1}$ & 90.92 & 91.85 & 82.31 & 82.11 & 110.21 & 112.33 \\
\hline $\mathbf{I}_{1} \mathbf{V}_{2}$ & 88.90 & 87.24 & 90.03 & 92.11 & 106.91 & 106.97 \\
\hline $\mathbf{I}_{1} \mathbf{V}_{3}$ & 88.63 & 89.42 & 109.31 & 107.80 & 101.41 & 102.63 \\
\hline $\mathbf{I}_{1} \mathbf{V}_{4}$ & 94.24 & 95.41 & 84.32 & 85.22 & 101.21 & 102.73 \\
\hline $\mathbf{I}_{2} \mathbf{V}_{1}$ & 86.26 & 89.61 & 79.21 & 81.91 & 105.81 & 105.87 \\
\hline $\mathbf{I}_{2} \mathbf{V}_{2}$ & 82.16 & 85.42 & 83.61 & 86.32 & 105.91 & 106.07 \\
\hline $\mathbf{I}_{2} \mathbf{V}_{3}$ & 84.44 & 87.22 & 105.32 & 108.81 & 101.11 & 102.83 \\
\hline $\mathbf{I}_{2} \mathbf{V}_{4}$ & 92.72 & 93.81 & 82.42 & 84.08 & 96.44 & 96.91 \\
\hline $\mathbf{I}_{\mathbf{3}} \mathbf{V}_{\mathbf{1}}$ & 84.37 & 86.26 & 76.91 & 82.61 & 103.14 & 104.30 \\
\hline $\mathbf{I}_{3} \mathbf{V}_{2}$ & 77.27 & 82.16 & 82.61 & 86.91 & 97.27 & 98.60 \\
\hline $\mathbf{I}_{\mathbf{3}} \mathbf{V}_{\mathbf{3}}$ & 79.54 & 84.44 & 102.70 & 106.71 & 98.34 & 99.90 \\
\hline $\mathbf{I}_{3} \mathbf{V}_{4}$ & 88.52 & 92.71 & 76.17 & 80.63 & 98.18 & 99.20 \\
\hline $\mathbf{I}_{4} \mathbf{V}_{1}$ & 80.91 & 84.35 & 75.83 & 82.42 & 100.63 & 103.11 \\
\hline $\mathbf{I}_{\mathbf{4}} \mathbf{V}_{2}$ & 70.91 & 77.25 & 80.22 & 86.61 & 97.27 & 99.71 \\
\hline $\mathbf{I}_{4} \mathbf{V}_{3}$ & 72.63 & 79.53 & 97.31 & 105.80 & 96.38 & 99.41 \\
\hline $\mathbf{I}_{4} \mathbf{V}_{4}$ & 94.25 & 95.42 & 70.51 & 78.72 & 96.31 & 98.21 \\
\hline S.Em \pm & 0.021 & 0.015 & 0.013 & 0.029 & 0.03 & 0.22 \\
\hline CD at $5 \%$ & 0.061 & 0.042 & 0.038 & 0.085 & 0.09 & 0.64 \\
\hline
\end{tabular}

$\mathrm{I}_{1}\left(100 \%\right.$ of FC); $\mathrm{I}_{2}\left(80 \%\right.$ of FC); $\mathrm{I}_{3}\left(60 \%\right.$ of FC); $\mathrm{I}_{4}(40 \%$ of FC)

$\mathrm{V}_{1}$ (Alphonso); $\mathrm{V}_{2}$ (Dashehari); $\mathrm{V}_{3}$ (Neelum); $\mathrm{V}_{1}$ (Totapuri). 


\section{Plant biomass}

The rootstock Totapuri under mild stressed condition recorded minimum plant biomass during stress period $(96.31 \mathrm{~g})$ and at recovery period $(96.91 \mathrm{~g})$. These findings are in conformity with Sakalauskaite et al., (2006). They reported that 50 per cent decrease in fresh and dry weights following five weeks of drought treatments in apple rootstocks.

By analyzing the various morphophysiological parameters under induced moisture stress condition, it was concluded that mango rootstocks Totapuri and Alphonso are found to be tolerant to moisture stress period with a characteristics of reduced plant growth, stem diameter, leaf area, plant biomass, stomatal density with higher relative water content and also having the ability of fast recovery after rewatering. Hence rootstocks Totapuri and Alphonso can act as potential source for drought tolerance.

\section{References}

Barrs, H. D. and Weatherley, P. E., 1962, A re-examination of relative turgidity technique for estimating water deficit in leaves. Austr. J. Biol. Sci., 15, 413428.

Bhatt and Srinivas Rao, 2005, Influence of pod load on response of okra to water stress. Indian J. Plant Physiol., 10(1): 54-59.

Jaleel, C. A., Manivannan, P., Wahid, A., Farooq, M., 2008, Drought stress in plants: a review on morphological characteristics and pigment composition. Int. J. Agric. Biol., 11(1): 100-105.

Kadam, J. H., 2001, Screening of grape rootstocks for drought tolerance. M.Sc. (Hort.) Thesis, Mahatma Phule Krishi Vidhyapeeth, Rahuri (India).

Luvaha, E., Netondo, G. W. and Ouma, G., 2011, Effect of water deficit on the growth, gas exchange and chlorophyll content of mango rootstock seedling. Acta. hortic., 9(11): 375-382.

Panse, V. G. and Sukhatme, P. V., 1985, Statistical methods for agricultural workers. ICAR. pub. New Delhi, p. 115-130.

Pavel, E. W. and Devilliers, A. J., 2004, Responses of mango trees to reduced irrigation regimes. Actahortic., 646: 63-68.

Sakalauskaite, J., Kviklys, D., Lanauskas, J. and Duchovskis, P., 2006, Biomass production, dry weight partitioning and leaf area of apple rootstocks under drought stress. Sodinink. darzinink., 25(3): 283-291.

Wolf, D. D., Carson, E. W. and Parrish, D. J., 1979, A replica method of determining stomatal and epidermal cell intensity. J. Agro. Edu., 8: 52-54.

Zaharah, S. S. and Razi, I. M., 2009, Growth, stomata aperture, biochemical changes and branch anatomy in mango (Mangifera indica) $\mathrm{cv}$. Chokanan in response to root restriction and water stress. Sci. Hortic., 123(1): 58-67.

\section{How to cite this article:}

Shanthala, L., R. K. Ramachandra, S. Mohan Kumar, G. S. K. Swamy, M. K. Honnabyraiah and Pallavi, H. M. 2021. Evaluation of Mango (Mangifera indica L.) Rootstocks under Induced Moisture Stress Condition for Various Morpho-Physiological Traits. Int.J.Curr.Microbiol.App.Sci. 10(05): 143-148. doi: https://doi.org/10.20546/ijcmas.2021.1005.019 